\title{
APPLICATION OF ELECTRICAL RESISTIVITY SURVEY FOR GROUNDWATER INVESTIGATION IN A BASEMENT ROCK REGION: A CASE STUDY OF AKOBO - IBADAN, NIGERIA ${ }^{*}$ NWANKWO, L.I., ${ }^{1}$ OLASEHINDE, P.I. ${ }^{2}$ and OSUNDELE, O.E. ${ }^{1}$ \\ http://dx.doi.org/10.4314/ejesm.v6i2.2
}

\author{
Received 28th May 2012; accepted 18th February 2013
}

\begin{abstract}
A geo-resistivity exploration has been carried out for groundwater within the Akobo catchment of the ancient city of Ibadan. The area lies within the basement rock terrain of South Western Nigeria and bounded by longitudes $3^{\circ} 51^{\prime}-3^{\circ} 53^{\prime} E$ and latitudes $7^{\circ} 22^{\prime}-7^{\circ} 24^{\prime} \mathrm{N}$. The exploration was done using SYSCAL KID meter while a total of 10 VES with an average of $46 \mathrm{~m}$ station interval were completed in 3 profiles by means of Schlumberger configuration with total current electrode spread of $160 \mathrm{~m}$. The results revealed that the area is underlain by four geo-electric layers. The top lateritic soil has resistivity values ranging from 28.1 to $481.8 \Omega \mathrm{m}$ and thickness of 0.8 to $5.7 \mathrm{~m}$. The second layer has sand/clay intercalation with resistivity values varying between 47.7 and $192.5 \Omega \mathrm{m}$ and thickness varying between 2.8 and $19.4 \mathrm{~m}$. The weathered/fractured basement has resistivity values from 106.2 to $846.8 \Omega \mathrm{m}$ with thickness of 13.2 to $24.9 \mathrm{~m}$ while the partly weathered/fresh basement layer has resistivities ranging from 130 to $856.4 \Omega \mathrm{m}$. The distribution of resistivities in the area shows that the weathered basement has a relatively low resistivity $(<200 \Omega \mathrm{m})$ values in the north-eastern and north-western axis coupled with high thickness values (> $20 \mathrm{~m}$ ) which suggests the presence of an aquiferous zone. Therefore, this portion of the study area could be highly hydro-geologically promising and maybe recommended for siting groundwater tube.
\end{abstract}

Key words: Geo-resistivity, groundwater, basement rock, borehole and Ibadan

\section{Introduction}

More than 300 million people in Africa today do not have access to clean water (Water for Africa, 2010). Many communities meet their daily water need from rivers, lakes, or reservoirs, sometimes using aqueducts or canals to bring water from distant surface water sources (Plummer et al., 1999; Water for Africa, 2010). Another important and more improved source is groundwater, the water that lies beneath the ground surface, filling the pore space between grains in bodies of sediment and clastic sedimentary rock, and filling cracks and crevices in all types of rock. The source of groundwater is rain and snow that falls to the ground. A portion of this precipitation percolates down into the ground to become groundwater. How much precipitation soaks into the ground is influenced by climate, land slope, soil and rock type, and vegetation. In general, approximately $15 \%$ of total precipitation ends up as groundwater, but that varies locally and regionally from 1 to $20 \%$. Despite the fact that global water distribution shows that groundwater is about $0.61 \%$, it is surprisingly, about 60 times as plentiful as fresh water in lakes and rivers on the surface (Plummer et al., 1999; Water for Africa, 2010).

Groundwater is therefore, a tremendous major economic resource, particularly in most cities of Nigeria where portable water is scarce. Many homes and organizations pump their required quantities of water from the ground because groundwater is commonly less polluted and more economical to use than surface water (Plummer $e t$ al., 1999).

Electrical resistivity survey is relevant to groundwater exploration (Olasehinde, 1999; Nwankwo et al., 2004; Singh et al., 2006; Alile et al., 2008; Ariyo and Adeyemi, 2009; Anudu, et al., 2011; Oyedele et al., 2011). The resistivity of rocks is strongly influenced by the presence of groundwater, which acts as an electrolyte. The minerals that form the matrix of a rock are generally good resistors than groundwater, so the resistivity of sediment decreases with the amount of groundwater it contains. This depends on the

\footnotetext{
${ }^{1}$ Department of Physics, University of Ilorin, 240003, Nigeria

${ }^{2}$ Department of Geology, Federal University of Technology, 
fraction of the rock that consists of pore spaces and the fraction of this pore volume that is waterfilled (Lowrie, 1997). Therefore, the analyses of such measurements could proffer targets for groundwater resource drilling.

The work presented in this paper is a case study employing electrical resistivity survey for groundwater exploration within the premises of IDC Primary School, Akobo (Ibadan) in Akinyele Local Government Area of Oyo State, Nigeria. The Akobo area and of course, most areas in the ancient city of Ibadan have been experiencing acute shortage of drinking water in recent times. The local Water Board is untiringly struggling to meet the increasing daily domestic and industrial demand of water in the area; as a result, there is the need to provide alternative potable water for the pupils and staff of the School.

\section{Materials and Method \\ Location and Geological Setting}

The area of study is situated within Akobo catchment of the ancient city of Ibadan, SouthWestern Nigeria. The area is bounded by longitudes $3^{\circ} 51^{\prime}-3^{\circ} 53^{\prime} \mathrm{E}$ and latitudes $7^{\circ} 22^{\prime}-7^{\circ}$ $24^{\prime} \mathrm{N}$ (Figure 1). The base map of the survey site is shown in Figure 2.

Nearly half of Nigeria is underlain by crystalline basement complex rocks (Rahaman 1973). The basement complex of Nigeria, which forms a part of the Africa crystalline shield, extends into the Dahomey in the West and into the Cameroon in the East. It outcrops widest in the central region of the Northern Nigeria where the younger granites have intruded it and porphyries of Jurassic age. The Nigeria Basement complex consists of at least four main groups of rocks: The Migmatite Gneiss complex, the Metasediment (composed of Schist, Calc-gneiss, Quartizite and Meta-conglumerate), the Porphyritic older granite and the miscellaneous rock types, which are mostly, post orogenic rocks like Aplite, Pegmatites, Dolerites dykes. These rocks are younger and are found to cut through pre-existing rocks.

The area of survey falls within Precambrian basement complex terrain. The main rock types found in Akobo and its environ are the undifferentiated granite gneiss, quartzite and porphyritic granite with schist impregnation. In this area, the occurrence of Precambrian basement rocks overlain by alternating sands and clay formation at alternating thick depth is observed. The terrain of the survey area is relatively flat; the predominant rock types are sandstone, migmatite gneiss/gneiss complex.

In basement complex environment, groundwater potential is determined by a complex inter-relationship between the geology, post emplacement tectonic history, weathering processes and depth, composition of the weathered layer, aquifer types and combination.

\section{Field Survey}

A total of 10 Vertical Electrical Sounding (VES) measurements with an average of $46 \mathrm{~m}$ station interval were completed using SYSCAL KID Resistivity meter in 3 profiles in the SE-NW direction. Each profile has an approximate length of $150 \mathrm{~m}$. Total current electrode spread of $160 \mathrm{~m}$ was utilized with the Schlumberger configuration.

\section{Basic Theoretical Considerations}

The fundamental equation for resistivity survey is derived from Ohm's law (Grant and West, 1965; Dobrin and Savit, 1988; Nwankwo, 2010):

$$
\rho=\frac{R A}{L}
$$

where $\rho$ is resistivity, $R$ is resistance, $L$ is length of homogenous conducting cylinder and $\mathrm{A}$ is cross sectional area.

For the solid earth, whose material is predominantly made up of silicates and basically non-conductors, the presence of water in the pore spaces of the soil and in the rock fractures enhances the conductivity of the earth when an electrical current $I$ is passed through it, thus making the rock a semi-conductor. Since the earth is not like a straight wire and it is anisotropic, then equation (1) is thus customized to:

$$
\rho=\frac{\Delta V}{I} .2 \pi r
$$

where $\Delta V$ is change in voltage and $\mathrm{r}$ is the radius of current electrode's small hemisphere.

Since the earth is not homogeneous, equation (2) is used to define an apparent resistivity $\rho_{a}$ which is the resistivity the earth would have if it were homogeneous (Grant and West, 1965):

$$
\rho_{a}=\frac{\Delta V}{I} \cdot 2 \pi r
$$


where $2 \pi r$ is then defined as a geometrical factor (G) fixed for a given electrode configuration.

The Schlumberger configuration was used in this work. The geometric factor $\mathrm{G}$ is thus given as:

$$
G=\pi \frac{\left[\left(\frac{A B}{2}\right)^{2}-\left(\frac{M N}{2}\right)^{2}\right]}{2\left(\frac{M N}{2}\right)}
$$

where $A B$ is (current electrode spacing) and $M N$ is (spacing between potential electrodes).

\section{Results and Discussion}

The results are presented as field curves in Figure 3. The curves are graphs expressing the variation in apparent resistivity with increasing depth. Most of the curves were the A-type $\left(\rho_{1}<\rho_{2}<\right.$ $\rho_{3}$ ) except at VES 4 and 8 which has the H-type $\left(\rho_{1}>\rho_{2}<\rho_{3}\right)$ curve. The shape of the VES curves depends on three factors: the thickness of each layer, the number of layers in the subsurface and the ratio of the resistivity of the layer.

Interpretation of the field curves are made and presented in Table 1. This interpretation result was used to generate three geo-electric sections (Figure 4). The geo-electric characteristics give the respective layer resistivity values and thickness. The sections identified a maximum of four geologic subsurface layers. The interpretation result in terms of geo-electric layering is as follows: First layer (Lateritic topsoil) composition varies from clay, sandy clay, clayey sand and laterite with resistivity values ranging between $28.1 \Omega \mathrm{m}$ to $481.8 \Omega \mathrm{m}$. The layer thickness varies between $0.8 \mathrm{~m}$ to $5.7 \mathrm{~m}$; the second layer (Sand/Clay Intercalations) is composed of clay, sandy clay and clayey sand. This layer is characterized with resistivity values varying from 47.7 to $192.5 \Omega \mathrm{m}$. The layer thickness varies between $2.8 \mathrm{~m}$ to $19.4 \mathrm{~m}$; third layer (Weathered/Fractured) is characterized by resistivity values ranging between 106.2 to $846.8 \Omega \mathrm{m}$. This range suggests a layer composed of clay, sandy clay and clayey sand. The characteristic resistivity values of some common basement rocks are shown in Table 2. The thickness of this unit varies from 13.2 to $24.9 \mathrm{~m}$. The overburden thickness varies from $0 \mathrm{~m}$ to 19.4 ; and lastly, the partly Weathered/Fresh Basement layer. This fourth layer consists of fresh and partly weathered basement of Resistivity values ranging from 130.0 to $856.4 \Omega \mathrm{m}$.

In order to characterize the water bearing units in the study area, resistivity distribution and isopach map (Figure 5) for the study area were produced. The major water bearing unit in the study area is the weathered basement. This is because of its supposed good porosity and permeability characteristics. Nevertheless, the water productivity of weathered basements greatly depends on the amount of clay materials present. In a basement complex terrain, the weathered layer and the fractured basement column constitute the two major aquifer units, the aquifers occur in five different forms. These include weathered layer aquifer, the weathered/fractured (unconfined) aquifer, weathered/fractured (unconfined)/fractured (confined) aquifer, weathered/fractured (confined) aquifer and fractured (confined) aquifer (Olorunfemi and Fasuyi, 1993).

The Resistivity distribution surface map (Figure 5-bottom) shows that the weathered basement has a relatively low resistivity value in the north-eastern and north-western axis which suggests the presence of an aquiferous zone. The southern part has a higher range of resistivity values which may not be consistent with water bearing zone. Deductions made from the isopach surface map for the weathered basement (Figure 5up) suggest that the weathered unit has a thickness ranging from 13.2 to $24.9 \mathrm{~m}$. As reported by Olorunfemi and Fasuyi (1993), the groundwater yield in basement complex terrain is generally low for clay bearing/low permeability weathered layer aquifer and high for weathered and fractured aquifer with enhanced permeability through secondary porosity. Moreover, Dogara et al. (1998) showed that the thickness of a weathered zone is vital in groundwater exploration. They inferred that the bigger the thickness, the more water accumulation capability of the zone. The characteristics of the central portion of the Northwestern axis of the study area, having low resistivities $(<200 \Omega \mathrm{m})$ coupled with high thickness values $(>20 \mathrm{~m})$, maybe consistent with the assertion. Therefore, the portion could be highly hydro-geologically promising.

Based on the geo-electrical characteristics of the study area, ground water tube development 
would be feasible around the central portion of the north-western axis (VES 2) with a drill depth of about 32m, while VES 3 and 7 may also be promising with an average drill depth of $38 \mathrm{~m}$. These field observations and interpretations are in conformity with comparable groundwater exploration studies conducted in hard rock terrains in Nigeria (e.g. Olorunfemi and Fasoyi, 1993; Olasehinde, 1999; Ariyo and Adeyemi, 2009; Anudu, et al., 2011; Oyedele et al., 2011).

\section{Conclusion}

The result presented in this work has attempted to define the sub-surface lithology and geo-electrical structure underlying a part of the Akobo area of Ibadan, Nigeria. The area is underlain by four layers of different lithological units; the aquifer thickness varies from 13.2 to $24.9 \mathrm{~m}$; the resistivity values of the weathered basement was found to be less than $200 \Omega \mathrm{m}$ and the central portion of the northeast-northwest axis (VES 2) has been found to be the most promising region for the exploitation of groundwater within the study area. Therefore, the portion is recommended for siting of groundwater tube.

\section{Acknowledgement}

The authors are grateful to Engr. Omisore Gbenga and Geo-Sore Multi-transaction Limited, Ibadan, Nigeria for their immense contributions made in this work.

\section{References}

Alile, M.O., Jegede, S.L. and Ehigiator, O.M., (2008). Underground water exploration using electrical resistivity method in Edo State, Nigeria. Asian Journal of Earth Sciences, 1, 38 -42

Anudu, G.K., Onuba, L.N. and Ufondu, L.S., (2011), Geoelectric sounding for groundwater exploration in the crystalline basement terrain around Onipe and adjoining areas, southwestern Nigeria. Journal of Applied Technology In Environmental Sanitation, 1 (4), 343-354.

Ariyo, S.O. and Adeyemi, G.O. (2009), Role of Electrical Resistivity Method for Groundwater

Exploration in Hard Rock Areas: A Case Study from Fidiwo/Ajebo Areas of Southwestern Nigeria. The Pacific Journal of Science and Technology, 10 (1), 483 - 486.
Dobrin, M.B and Savit, C.H. (1988), Introduction to geophysical prospecting. $2^{\text {nd }} \mathrm{Ed}$. London.

McGraw-Hill book company.

Dogara, M.D., Dewu, B.M., and Ajayi, C.O., (1998), Groundwater potential of Romi, Kaduna.

Nig. Journ. of Physics. 10, $85-90$.

Grant, F.S and West, G.F. (1965) Interpretation theory in applied geophysics. McGraw-Hill book company. London

Lowrie, W. (1997) Fundamentals of Geophysics. Cambridge Press. London

Nwankwo L.I. (2010), 2D Resistivity survey for groundwater exploration in a hard rock terrain: A

case study of MAGDAS Observatory, UNILORIN, Nigeria. In consideration by Asian

Journal of Earth Sciences.

Nwankwo L.I., Olasehinde, P.I. and Babatunde, E.B. (2004), The use of Electrical Resistivity

Pseudo-section in elucidating the geology of an east-west profile in the Basement Complex terrain of Ilorin, West-Central Nigeria. Nig, Journ. of Pure \& Appl. Sc. 19, 1672-1682.

Olasehinde, P.I. (1999), An integrated geological and geophysical exploration for groundwater in the basement complex of west central Nigeria. Water resourses, 10, 46-49.

Olorunfemi, M.O and Fasuyi, S.A. (1993), Aquifer types and the geoelectric/hydro geologic

characteristic of part the central basement terrain, Niger State. Journal of Africa Earths Sciences, 16, 309-317

Oyedele, K. F., Ogagarue D. O. and Esse, O., (2011), Groundwater Potential Evaluation using

Surface Geophysics at Oru-Imope, South-Western Nigeria. European Journal of Scientific Research, 63 (4), 515-522.

Plummer, C.C., McGeary, D. and Carlson, D.H., (1999), Physical Geology. $8^{\text {th }}$ Ed. London.

McGraw-Hill book company.

Rahaman, M.A. (1973), Review of the basement geology of south western Nigeria. In C.A. Kobe

(Editor) Geology of Nigeria. 2ed. Rockview publishers, Jos.

Singh, K.K.K., Singh, A.K.S., Singh, K.B. and Sinha, A., (2006), 2D resistivity imaging survey for siting water-supply tube wells in metamorphic terrains: A case study of CMRI campus, Dhanbad, India. The leading Edge, 25, 1458 -1460.

Water for Africa, 2010.

http://www.waterforafrica.org.uk/ 


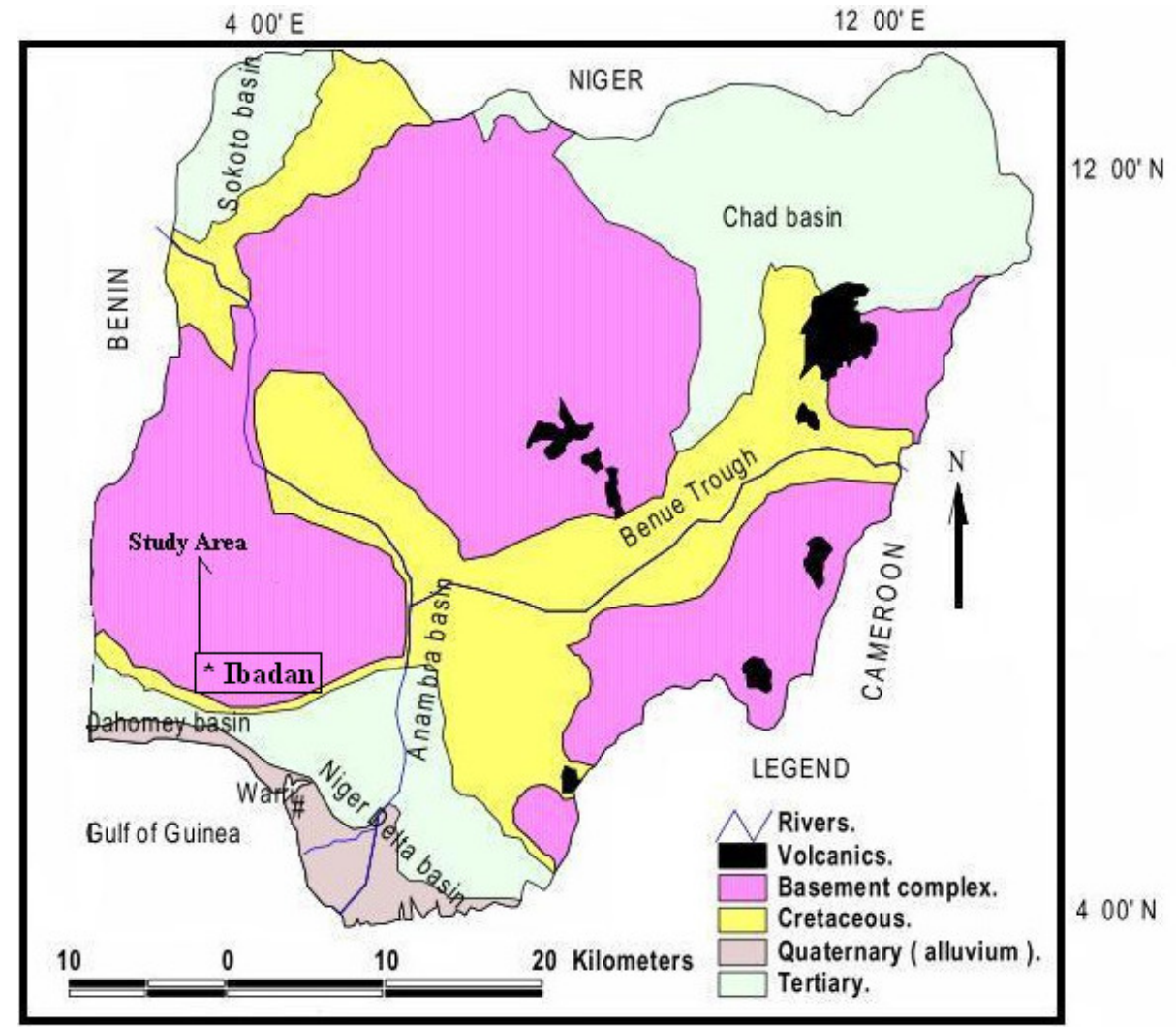

Figure 1 Geological map of Nigeria showing the study area

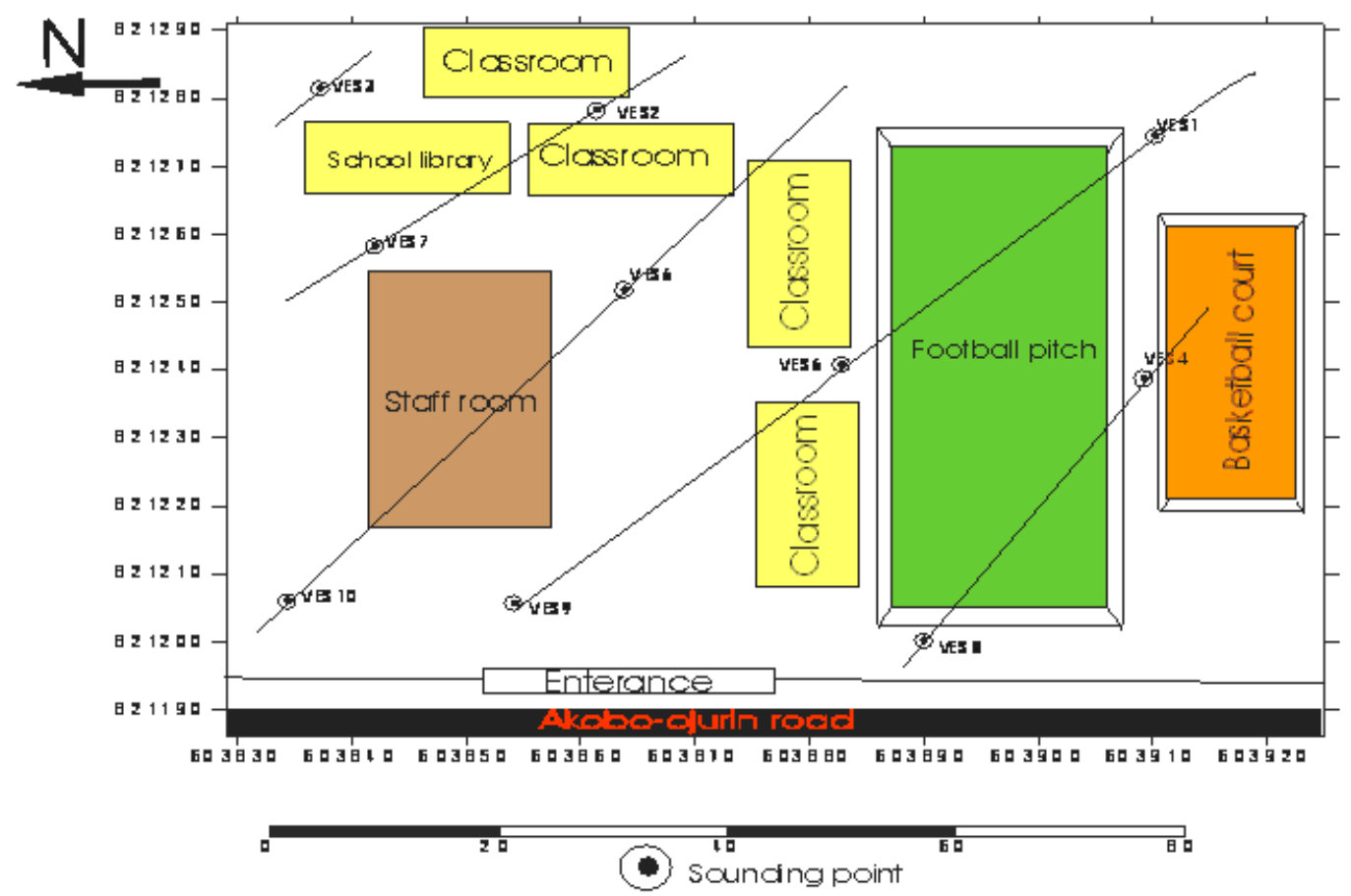

Figure 2 Base map of the study area 
Application of Electrical Resistivity Survey for Groundwater.....................Nwankwo et al.

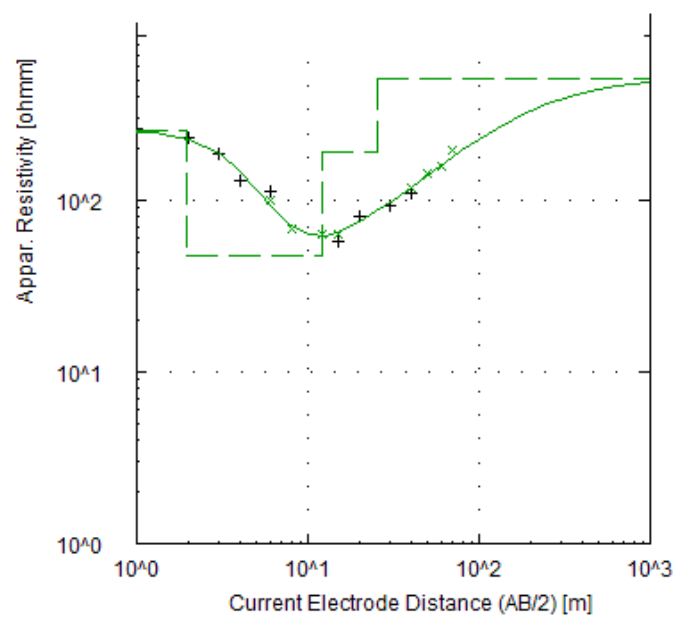

a. VES 1

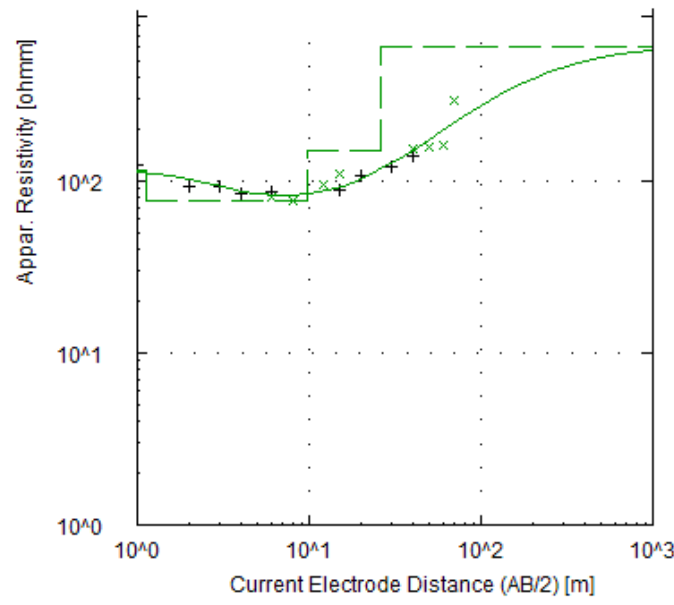

c. VES 3

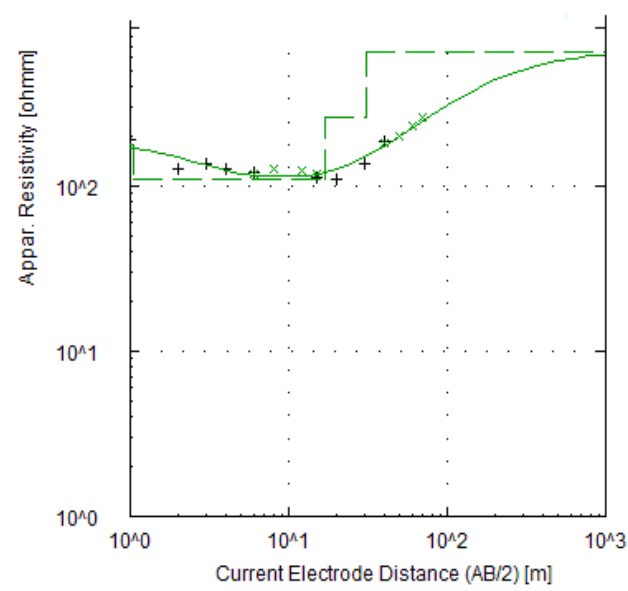

e. VES 5

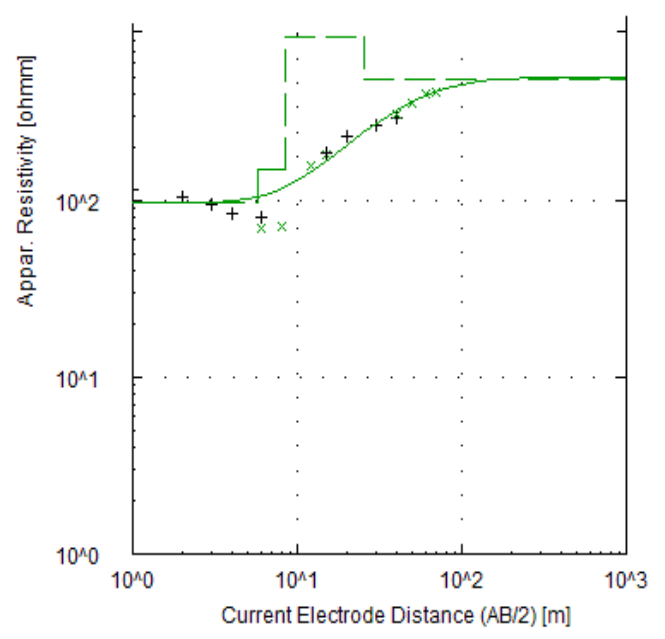

b. VES 2

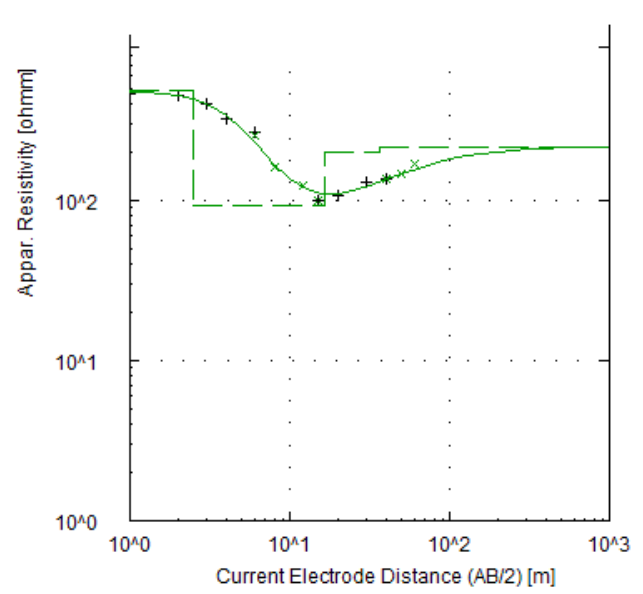

d. VES 4

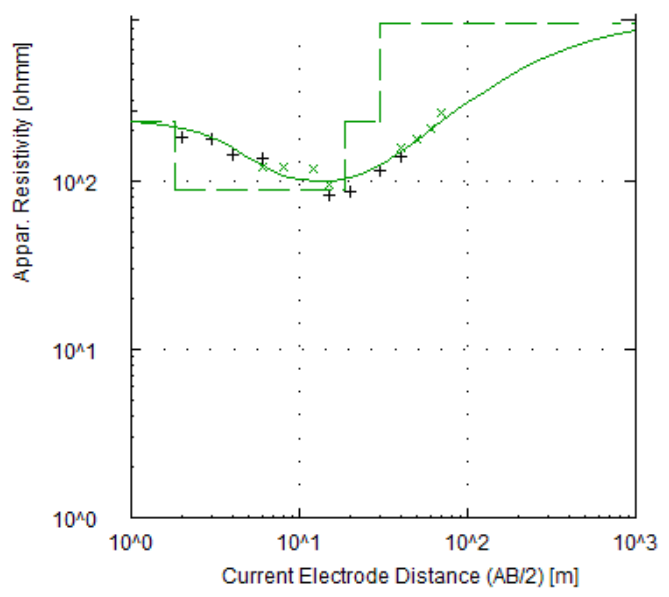

f. VES 6 

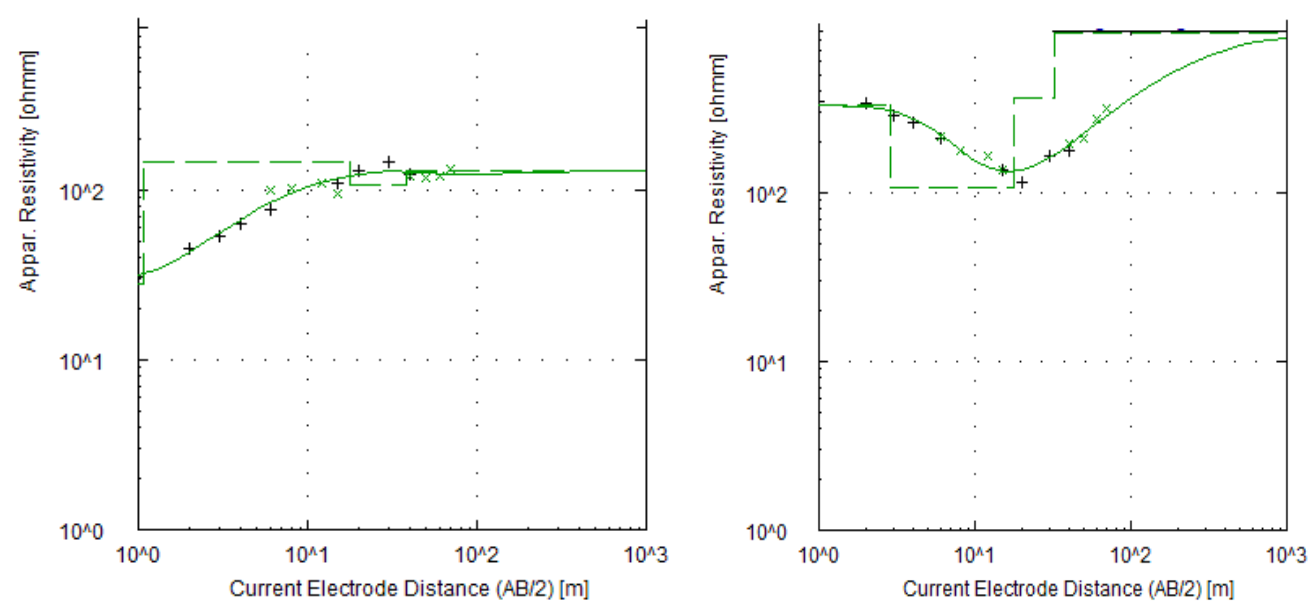

g. VES 7

h. VES 8

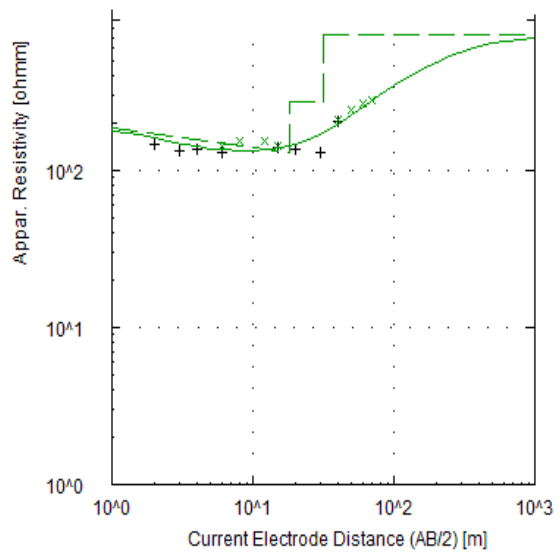

i. VES 9

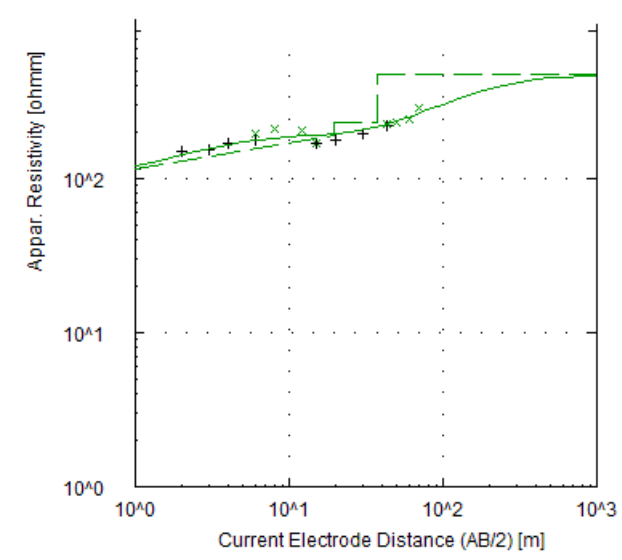

j. VES 10.

Figure 3. Vertical Electrical Sounding (VES) curves of the study area

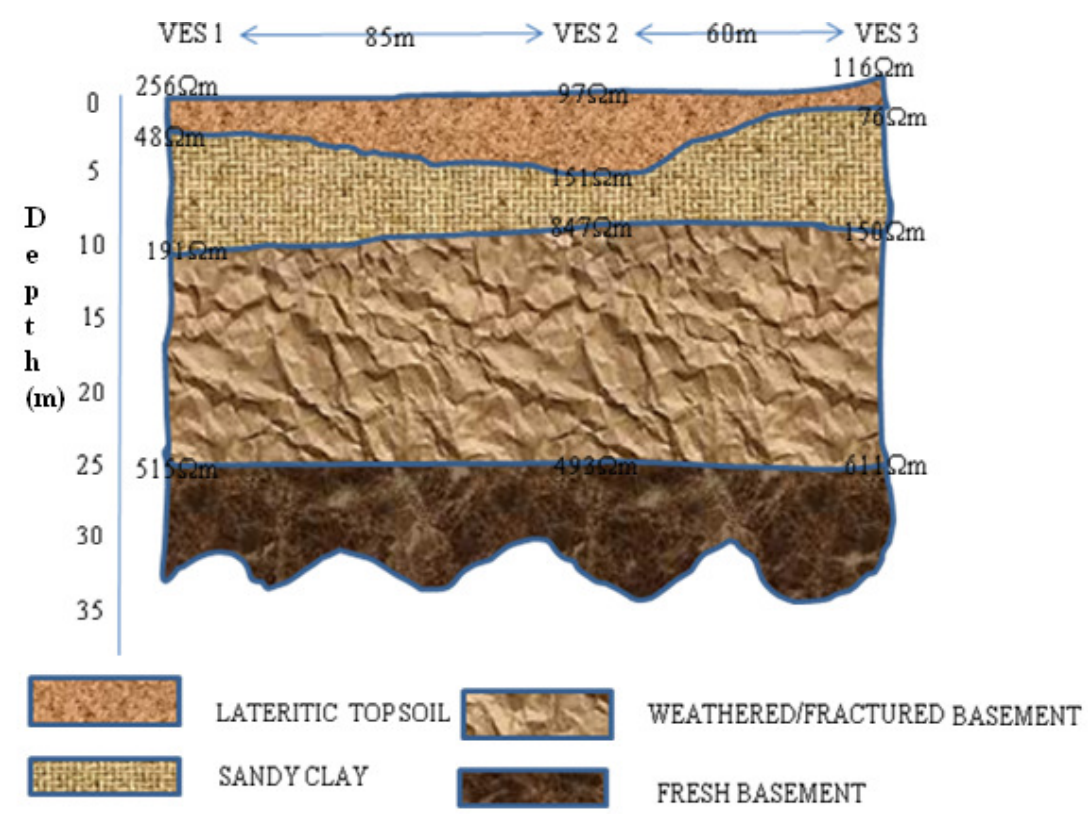

a. Profile 1 

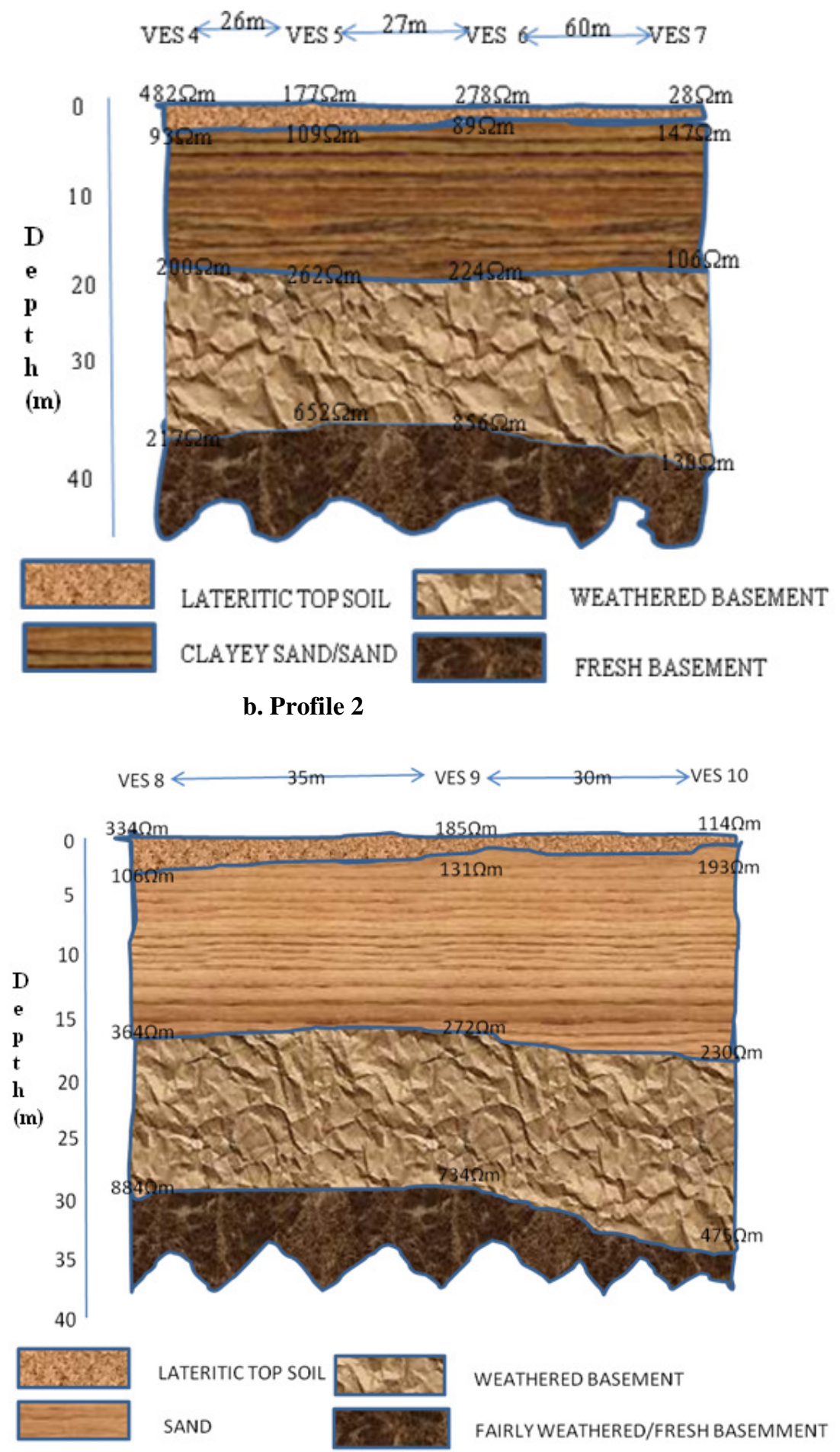

c. Profile 3

Figure 4 Geo-electric Sections (SE-NW Direction) 


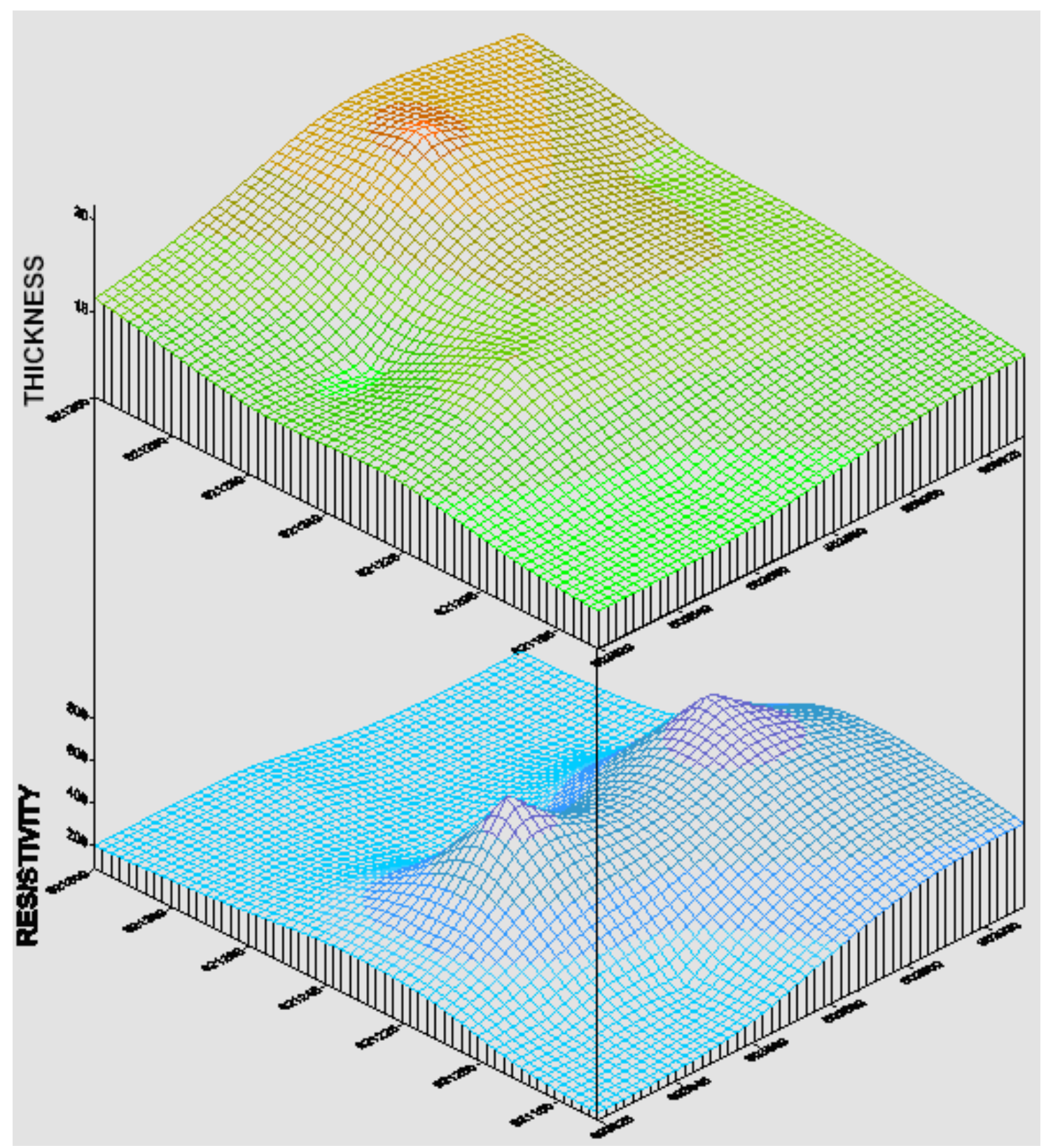

Figure 5 Resistivity distribution and Isopach map of the weathered basement layer 
Table 1 Interpretation of the results

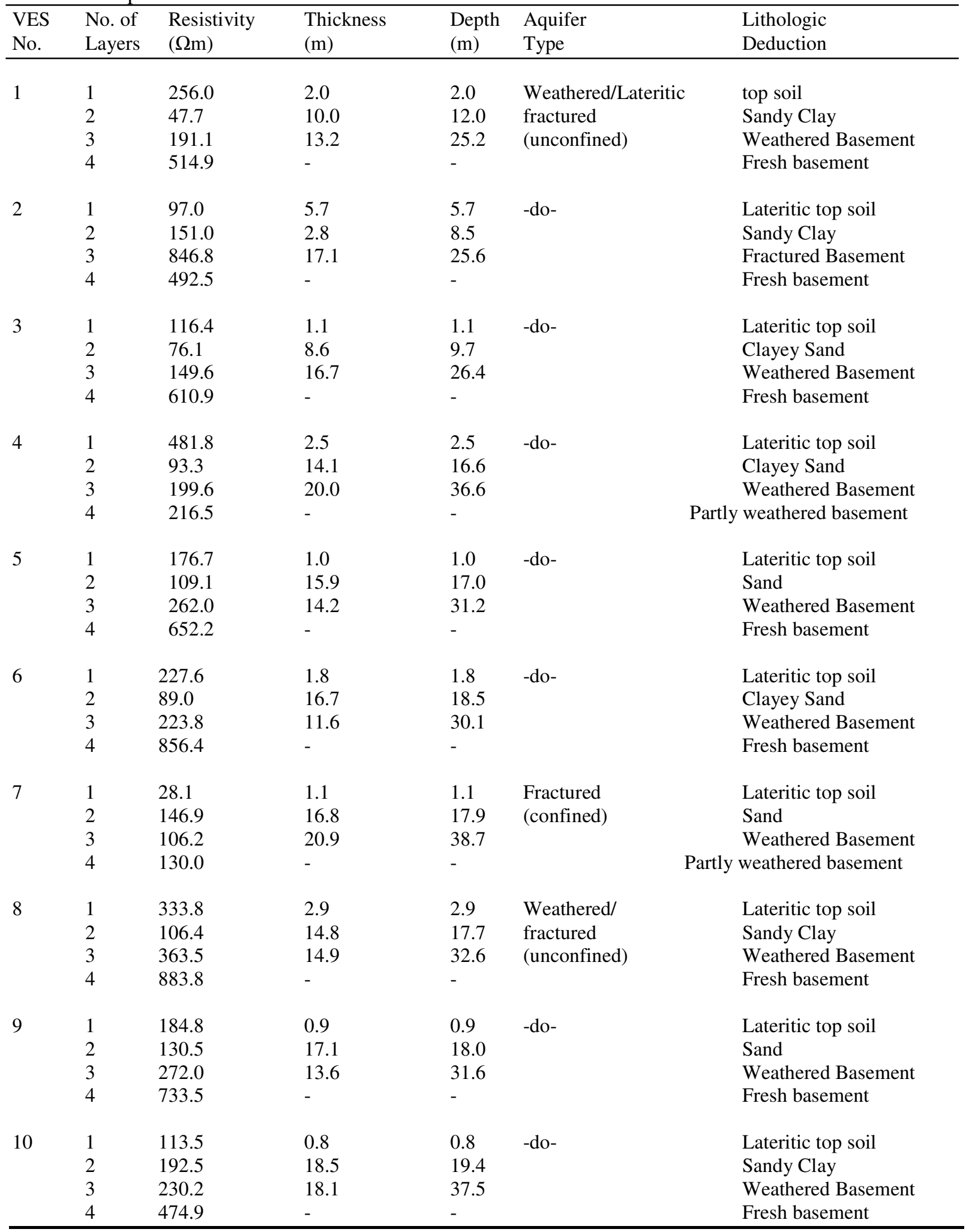


Ethiopian Journal of Environmental Studies and Management Vol. 6 No.22013

Table 2 Ranges of electrical resistivity of some common rocks, soils and ores (after Lowrie, 1997)

\begin{tabular}{cll}
\hline Material & & Resistivity $(\Omega \mathrm{m})$ \\
\hline Rocks & Granite & $5 \times 10^{3}-10^{6}$ \\
& Basalt & $50-10^{5}$ \\
& Jointed, fractured & \\
\& flow top basalt & $1-100$ \\
& Fresh granite & $5 \times 10^{2}-5 \times 10^{4}$ \\
& Weathered or & $1-100$ \\
& altered granite & $10-10^{4}$ \\
& Limestone & $10-10^{3}$ \\
& Argillite & $1-10^{3}$ \\
& Sandstone & $10^{-3}-50$ \\
& Graphitic schist & $10^{2}-10^{4}$ \\
& Gravel & $1-10^{3}$ \\
& Alluvium & $1-100$ \\
& Clay & $10^{-1}-5 \times 10^{2}$ \\
& Hematite & $10^{-4}-1$ \\
& Chalcopyrite & $10^{-4}-5 \times 10^{-2}$ \\
& Graphite & $10^{-5}-5 \times 10^{-3}$ \\
& Pyrrhotite & \\
\hline
\end{tabular}

